Ann. Biol. anim. Bioch. Biophys., 1979, 19 (4 B), 1211-1217.

\title{
Development of sexual differences in the embryonic genitals
}

\author{
par L. J. PELLINIEMI, P.-L. KELLOKUMPU-LEHTINEN, L. LAUTEALA \\ Laboratory of Electron Microscopy and Department of Anatomy, University of Turku, \\ Kinamyllynkatu 10, SF-20520 Turku 52, Finland.
}

Summary. Sexual differentiation and prenatal development of the gonads and the associated paramesonephric ducts were studied with the electron microscope in human and pig embryos. We wanted to elucidate the mechanisms and regulatory relationships involved in these various organogenetic events which lead to the formation of morphologically and functionally different organs from similar primordia in male and female individuals.

In the first phase of differentiation the initially indifferent gonads differentiate histologically into testis or ovary. Testis is identifiable in man in the seventh week and in the pig at the age of 26 days. The ovary differentiates during the following week in both species. The second occurrence after the initial gonadal differentiation is the differentiation of the Leydig cells in the male gonad by the end of the eighth week in the human and by the age of 30 days in the pig. The third occurrence starts, when testosterone and antimüllerian hormone begin to modify the development of the mesonephric and paramesonephric ducts, respectively. The fourth occurrence in genital sex differentiation is the initiation of meiosis in the female germ cells at the age of three months in the human.

Our results indicate that there are no ultrastructural sexual differences in the gonads prior to the formation of the testicular cords. The cord cells as well as the interstitial cells both seem to be derivatives of a common indifferent blastema in the medulla of the indifferent gonad. The H-Y antigen theory of testicular differentiation appears to be in agreement with the morphological findings. The fetal interstitial Leydig cells apparently differentiate from primitive precursors in the interstitium after the formation of the testicular cords. The germ cells in the male remain quiescent with a pale cytoplasm and only few organelles whereas in the female the nucleus is larger and the cells contain more organelles. The regression of the male paramesonephric duct starts after formation of circular fibroblast layers from the mesenchymal cells around the duct. The epithelial cells decrease in height and show autolytic changes. The present findings suggest that the mesenchymal cells may be involved in the action of the antimüllerian hormone.

\section{Introduction.}

Prenatal sexual differentiation in mammals is characterized by a biphasic regulatory system in the male and by a monophasic system in the female (Jost ef al., 1973). In the first, or genetic phase, regulation is carried out in both sexes by the appropriate genes in the differentiating cells of the gonads and other genitals. The genetic phase governs the whole prenatal sex differentiation in the female. In the male genetic regulation is also functional throughout prenatal development, but after gonadal sex dif- 
ferentiation the genetic mechanisms are modified by factors representing the second, or hormonal phase. The $\mathrm{H}-\mathrm{Y}$ antigen theory of Wachtel et al. (1975) provides an interesting ground for further studies of gonadal sex differentiation. Another recent development is the characterization of the antimüllerian hormone (Josso ef al., 1977), which has filled a significant gap in the information about the hormonal phase. The factors probably involved in the regulation of germ cell meiosis in the prenatal period (Byskov, 1978) further emphasize the role of the somatic cells as the principal regulators of the various stages of genital sex differentiation.

We wanted to investigate how these new findings would match with morphological changes in the differentiating cells as revealed by transmission electron microccopy.

\section{Materials and methods.}

The human fetuses were obtained from legal abortions. The crown-rump lengths (CR) ranged from 29 to $130 \mathrm{~mm}$, corresponding to the ages of 8 to 15 weeks (Streeter, 1920). The pig embryos were produced by artificial insemination and their ages were 24 to 63 days. The specimens were fixed with $0.24 \mathrm{~mol} / \mathrm{l}$ glutaraldehyde followed by $0.04 \mathrm{~mol} / \mathrm{l}$ osmium tetroxide and processed for electron microscopy as previously described (Pelliniemi, 1975).

\section{Results.}

Morphological differentiation of the testis. - The male and female gonads in the pig are morphologically similar at the age of 24 days. They consist of surface epithelium, which continues as primitive cords into the gonadal blastema in the medulla. The blastema is composed of cells similar to those in the deep layers of the surface epithelium and in the primitive cords. The blastemal tissue in the male gonad differentiates into testicular cords and interstitium by the age of 26 days. The primordial germ cells that have been randomly distributed among the blastemal cells are enclosed in the cords. The testicular cord cells resemble ultrastructurally the cells in the primitive cords. The cell membranes of adjacent cord cells are in direct apposition. The basal surface facing the interstitium is smooth and covered by a partially discontinuous basal lamina. The lateral surfaces of adjacent cord cells are linked together by discontinuous zonula adherens-like junctions. In the initial phase the testicular cords are actually anastomosing sheets and the interstitium has more a cord-like organization. The early interstitial tissue consists of blood vessels and undifferentiated mesenchymal cells. The interstitial spaces are wide and the cells are in contact with each other through partial areas of their cytoplasmic processes. The gonads of the female pig embryo continue to grow in size, but remain morphologically in the indifferent stage during the sex-specific morphogenetic differentiation of the male gonad.

FIG. 1. - Electron micrograph of a human festicular cord at the age of 10 weeks composed of fetal spermatogonia $(G)$ and sustentacular cells (S). Scale $8800: 1$. 
Differentiation of the fetal Leydig cells. - The appearance of fetal Leydig cells in the testicular interstitium in the eighth week in the human and by the age of 30 days in the pig is the next occurrence in gonadal sex differentiation after the formation of the testicular cords. Immature fetal Leydig cells have a roughly spherical nucleus with a prominent nucleolus. The amount of cytoplasm is much greater than in the mesenchymal cells and contains areas of agranular endoplasmic reticulum and cisternae of granular endoplasmic reticulum arrayed in parallel. The cells grow in size and the cytoplasm becomes tightly packed with agranular endoplasmic reticulum by the age of 12 weeks in the human and 34 days in the pig.

Regression of the paramesonephric duct. - The gradual elimination of the paramesonephric duct in the male is the first occurrence in extragonadal or somatic differentiation, being at the same time the third difference between the male and female sex. The initial sign in the process leading to the regression of the human and pig paramesonephric ducts is the differentiation of the surrounding mesenchymal cells into several layers of fibroblasts around the duct. Subsequently, the height of the epithelial cells decreases and the lumen obliterates. Autolytic inclusion bodies appear in the cyloplasm, and dark and light cells become a dominant feature. Our present incomplete observations have not revealed macrophages in the regressing ducts.

Initiation of meiosis. - The germ cells remain passive during the early stages of genital differentiation. The first process occurring in the female and providing the fourth difference between the two sexes is the initiation of oogonial meiosis. Ultrastructurally there are marked differences between the male (fig. 1) and the female (fig. 2) germ cells at the age of 10 weeks in the human. The oogonia are in clusters surrounded by follicular cells and have a large spherical nucleus with several prominent nucleoli. The cytoplasm is densely stained and contains a great number of free polysomes, spherical mitochondria, a Golgi complex and some granular endoplasmic reticulum. The male fetal spermatogonia are conspicuous among the sustentacular cells because of their pale cytoplasm. The main difference between the sexes is the lower number of free polysomes in the spermatogonia.

\section{Discussion.}

The formation of the testicular cords from the indifferent gonadal blastema is apparently based on a recognition mechanism between the prospective cord cells. Additionally, they have to join to each other with the cell membranes apposed and, in so doing, to form a certain histological pattern, the testicular cords. Another recognition and association mechanism is functional between the cord cells and the primordial germ cells which become enclosed in the cords. The synthesis and secretion of the components for the basal lamina covering the cord surface facing the interstitium are activated simultaneously during cord organization. The suggestion of the

FIG. 2. - Electron micrograph of a human ovary at the age of 10 weeks composed of several large oogonia $(O)$ and some follicular cells $(F)$. Scale $8800: 1$. 
ubiquitous expression of the regulatory factor, the $\mathrm{H}-\mathrm{Y}$ antigen, on the surface of the gonadal cells $(O h n o, 1976)$ is in agreement with the present morphological findings. Further development of the theory, however, is required to provide explanations for several remaining problems. Why do the cord and interstitial cells separate even though they contain the same genotype? Wat initiates differentiation in the proper part of the gonad and at the proper time? How does the same antigen on the cell surface organize testicular cords in mammals and ovarian follicles in birds?

The Leydig cell differentiation and the initiation of androgen synthesis are generally thought to be regulated by the chorionic gonadotropin (Niemi ef al., 1967). The demonstration of receptors for human chorionic gonadotropin $(\mathrm{hCG})$ and the positive effect of hCG on testosterone synthesis in human fetal testis (Huhtaniemi ef al., 1977). as well as the histochemical localization of hCG in rat fetal Leydig cells (Childs et al., 1978), further support the role of hCG in Leydig cell regulation. A more detailed study of the mechanism of hCG action is needed to elucidate wheter the hCG will induce the synthesis of the androgen pathway enzymes, or activate pre-existing enzymes. Additionally, the relationship between the presence of agranular endoplasmic reticulum and the ability to synthesize various steroids requires closer analysis. The mechanism timing the hCG response in the target cells is also still unknown.

The fetal sustentacular cells are probably the origin of the antimüllerian hormone (Josso et al., 1977). The present results suggest that mesenchymal cells can be mediators of the regressing action of the hormone on the epithelial cells. Strikingly similar morphological development of the mesenchyme is seen in the androgeninduced degeneration of the mammary bud in male fetal mice (Kratochwil, 1977). In that system the target for the androgens is the mesenchyme surrounding the epithelium. The mesenchymal cells are postulated to secrete a factor inducing epithelial involution. A similar mechanism could be functional in paramesonephric regression. The invasion of macrophages was seen when the regression was induced in the culture of rat paramesonephric duct (Price et al., 1977). The secretory activity of the sustentacular cells remains a dilemma for morphologists. A sufficient amount of granular endoplasmic reticulum for protein synthesis is present, but typical secretory vesicles are difficult to find. The regulation of antimüllerian hormone synthesis is unknown, and its exact route to the target remains to be clarified.

The initiation of meiosis in the female fetal germ cells is apparently the explanation for the higher number of free polysomes in the fetal oogonia than in the fetal spermatogonia. The RNA is probably used for the synthetic reactions preceding meiotic division. Experimental evidence suggests that the meiosis-regulating factors are synthesized in the somatic cells of the gonad (Byskov, 1978). The discovery of mechanisms involved in meiosis regulation may have a potential value in male fertility control. If the meiosis inhibiting factor can be purified or synthesized, it could provide a natural and reversible method of male contraception.

4th Workshop on "Development and maturation of the reproductive organs and functions $\gg$ Luynes, France, octobre 1978.

Acknowledgments. - We thank Ms. M. Aaltonen, Mrs. Sirpa From, Ms. U. Mäntylä, Mr. M. Lehtimäki and Ms. Anne Ahern for skillful assistance in the laboratory and 
office work. Support by the Wäinö Edward Miettinen Foundation and the Scientific Research Foundation of Lääke Oy is gratefully acknowledged.

Résumé. Chez l'homme et le porc, la différenciation sexuelle des gonades et leur développement pendant la vie fotale, ainsi que des canaux mésonéphriques qui leur sont associés, ont été étudiés en microscopie électronique. Nous avons cherché à élucider les relations et les méçanismes impliqués dans cette organogenèse qui conduit à la formation d'organes morphologiquement et fonctionnellement différents chez le mâle et chez la femelle à partir d'ébauches semblables.

La différenciation histologique en un ovaire ou un testicule se produit pendant la première dédifférenciation. Le testicule est identifiable chez l'homme durant la 7 e semaine et chez le porc à l'âge de 26 jours. L'ovaire se différencie dans les 2 espèces pendant la semaine suivante. La seconde phase est caractérisée par la différenciation de cellules de Leydig dans le testicule. Elle a lieu à la fin de la $8^{e}$ semaine chez l'homme et à l'âge de 30 jours chez le porc. La troisième phase débute quand la sécrétion de testostérone ef de l'hormone antimullérienne commence à entraîner un changement dans le développement des canaux mésonéphrétiques ef paramésonéphrétiques. La quatrième phase de la différenciation sexuelle est marquée par l'initiation de la méiose dans les cellules germinales femelles, qui se produit à 3 mois chez le fœtus humain.

Nos résultats indiquent qu'il n'y a pas de différence sexuelle au niveau ultrastructural entre les gonades avant la formation des cordons dans le testicule. Les cellules des cordons, aussi bien que celles de l'interstitielle, semblent dériver d'un blastème commun, indifférencié, de la médulla de la gonade primordiale. La théorie du rôle de l'antigène $H$-Y dans la différenciation testiculaire s'accorde avec les observations morphologiques. Les cellules de Leydig fœales se différencient apparemment à parfir de précurseurs de l'interstitium après la formation des cordons. Les cellules germinales mâles restent quiescentes avec un cytoplasme pâle.

\section{References}

BYSKOV A. G., 1978. Regulation of initiation of meiosis in female gonads. Int. J. Androl., Suppl. 2, 29-38.

CHILDS G. W., HON C., RUSSELL L. R., GARDNER P. J., 1978. Subcellular localization of gonadotropins and testosterone in the developing fetal rat testis. J. Histochem. Cytochem., 261, 545-564.

HUHTANIEMI I. T., KORENBROT C. C., JAFFE R. B., 1977. hCG binding and stimulation of testosterone biosynthesis in the human fetal testis. J. clin. Endocr. Metab., 44, 963-967.

JOSSO N., PICARD J.-Y., TRAN D., 1977. The antimullerian hormone. Rec. Progr. Hormone Res., 33, 117-167.

JOST A., VIGIER B., PRÉPIN J., PERCHELLET J. P., 1973. Studies on sex differentiation in mammals. Rec. Progr. Hormone Res., 29, 391-396.

KRATOCHWIL K., 1977. Development and loss of androgen responsiveness in the embryonic rudiment of the mouse mammary gland. Devel. Biol., 61, 358-365.

NIEMI M., IKONEN M., HERVONEN A., 1967. Histochemistry and fine structure of the interstitial tissue in the human foetal testis, 31-55. In WOLSTENHOLME G. E. W., O'CONNOR M. Endocrinology of the testis, Ciba Found. Coll. Endocrinol. vol. 16, Little, Brown and Co Boston.

OHNO S., 1976. Major regulatory genes for mammalian sexual development. Cell, 7, 315-321.

PELLINIEMI L. J., 1975. Ultrastructure of gonadal ridge in male and female pig embryos. Anot. Embryol., 147, 19-34.

PRICE J. M., DONAHOE P. K., ITO Y., HENDREN W. H. III, 1977. Programmed cell death in the Müllerian duct induced by Müllerian inhibiting substance. Amer. J. Anat., 149, 353-376.

STREETER, G. L., 1920. Weight, sitting height, head size, foot length, and menstrual age of the human embryo. Contrib. Embryo. Carnegie Inst., Washingion, 11, 143-178.

WACHTEL S. S., OHNO S., KOO G. C., BOYSE E. A., 1975. Possible role for H-Y antigen in the primary determination of sex. Nature (Lond.), 257, 235-236. 